\title{
Effects of water levels and soil nutrients on the growth of Iris laevigata seedlings
}

Eun Hye Lee ${ }^{1 \dagger}$, Bo Eun Lee ${ }^{1 \dagger}$ and Jae Geun $\operatorname{Kim}^{1,2^{*}}$ (D)

\begin{abstract}
Iris laevigata is geographically restricted and legally protected in Korea. In this study, a mesocosm study was conducted to examine the effects of environmental conditions such as water levels and soil nutrient conditions on the growth and survival of I. laevigata seedlings. Complete submergence lowered the total number of leaves, biomass, and survival rates. A rise in soil nutrients increased overall seedling growth and increased tiller numbers via the promotion of asexual reproduction. Also, we found that the lowest measured values of seedlings are associated with the most stressful condition due to the interaction of low soil nutrients and high water levels. I. laevigata seedlings, however, are distributed in low-nutrient habitats such as floating mat, even though they do not grow well under these conditions. This study suggests that l. laevigata does not prefer low-nutrient condition but choose another benefit such as low competition. Also, the water level must be lower than the seedling height for effective growth and management of I. laevigata.
\end{abstract}

Keywords: Endangered species, Fundamental niche, Seedling establishment, Soil nutrients, Water depth

\section{Background}

Iris laevigata Fisch. (Iridaceae) belongs to a large genus comprising more than 300 herbaceous species growing in the temperate regions of the northern hemisphere (Rodionenko 1987). Because I. laevigata is geographically restricted to a very few habitats in Korea, it is classified as extremely rare and designated as a 2nd-grade endangered plant species in the country (Korea Forest Service and Korea National Arboretum 2008, Ministry of Environment 2012, National Institute of Biological Resources 2012). However, a few studies, mainly cytogenetical in design, have been conducted on these rare plants (Sun et al. 2012, Yabuya 1987, 1991). Because of the need to conserve and restore the habitat of these endangered species, it is important to also collect information on the biological and ecological characteristics of the plant (Orians and Soulé 2001).

An understanding of the life cycle of a plant, such as the method of reproduction, seed dispersion, and germination, and survival conditions of seedlings is

\footnotetext{
*Correspondence: jaegkim@snu.ac.kr

${ }^{\dagger}$ Equal contributors

'Department of Biology Education, Seoul National University, Seoul 08826, South Korea

${ }^{2}$ Center for Education Research, Seoul National University, Seoul 08826, South Korea
}

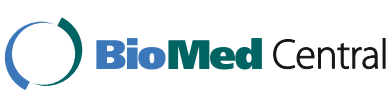

C The Author(s). 2018 Open Access This article is distributed under the terms of the Creative Commons Attribution 4.0 International License (http://creativecommons.org/licenses/by/4.0/), which permits unrestricted use, distribution, and reproduction in any medium, provided you give appropriate credit to the original author(s) and the source, provide a link to the Creative Commons license, and indicate if changes were made. The Creative Commons Public Domain Dedication waiver (http://creativecommons.org/publicdomain/zero/1.0/) applies to the data made available in this article, unless otherwise stated. (Mahoney and Rood 1998). The seedling establishment phase of the life cycle is crucial to successful propagation of any plant. Notably, the water level is the most important factor affecting seedling survival and the establishment of submerged plants (Nicol and Ganf 2000, Fraser and Karnezis, 2005, Kwon et al. 2007). Water level determines wetland plant community composition and zonation because of different response and adaptation of species (Casanova and Brock 2000).

In Korea, I. laevigata grows as a floating mat when the seasonal water level fluctuations are less than $10 \mathrm{~cm}$ and the available nutrients to the plants are low (Kim et al. 2013, Lee and Kim 2014). It is important to identify the fundamental niche occupied by some species in lownutrient environments. For example, some rare species tend to be restricted to a poor nutrient habitat because of more specialized resource requirements or a limited range of physiological tolerance levels (Gaston and Kunin 1997). To the best of our knowledge, no previous study has examined the relationship between the growth of I. laevigata and soil nutrients.

So, we focused on independent and potentially interacting effects of two environmental factors, i.e., water level and soil nutrients on the growth of I. laevigata seedlings. The 
specific objectives of this paper are as follows: (1) to determine the impact of water level and soil nutrients on the growth of I. laevigata seedlings and (2) to provide specific ecological information about I. laevigata population management through examination of the seedlings.

\section{Methods}

\section{Study material}

The seeds of I. laevigata were collected from a natural habitat in Goseong-gun, Gangwon province, in August 2014 for an Eco-Innovation project initiated by the Ministry of Environment. Seeds were sealed in a plastic bag and stored under humid and dark conditions at $4{ }^{\circ} \mathrm{C}$ until the start of each experiment. Based on conditions that gave highest germinations and survival rates in a preliminary experiment, seeds were germinated and seedlings were grown in a growth chamber $\left(25^{\circ} \mathrm{C} / 15{ }^{\circ} \mathrm{C}\right.$, $14 \mathrm{~h}$ photoperiod, sand substrate) for 2 weeks. Seedlings were adjusted to experimental conditions for 1 week to reduce transplant stress. Only three-weeks-old seedlings with the height of $10 \pm 2 \mathrm{~cm}$ were selected and transplanted individually into the pots.

\section{Experimental treatments}

This research was conducted from June to September 2017. Three water levels and three soil nutrient levels were chosen for the experimental treatments, and the seedlings were planted under a combination of these conditions. Water levels were adjusted to $10 \mathrm{~cm}$ below (group - 10), $0 \mathrm{~cm}$ (group 0), and $10 \mathrm{~cm}$ above (group + 10) the soil surfaces. The soil nutrients consisted of sand (low, group L), 1:4 mixture of nursery soil (DongbuHannong, Korea) and sand (medium, group M), and 1:1 mixture of nursery soil and sand (high, group H). Water level refers to the environment of the native habitat of each plant (Kim et al. 2013). $\mathrm{NO}_{3}-\mathrm{N}, \mathrm{NH}_{4}-\mathrm{N}$, and $\mathrm{PO}_{4}-\mathrm{P}$ in the extracted soil solution before and after experiment indicated that the gradient of soil nutrients increasing from group $\mathrm{L}$ to group $\mathrm{H}$ was consistent from the beginning to the end of the experiment (Table 1). Low- and mid-soil nutrient settings refer to the habitat or the environment of Iris species such as Iris pseudacorus, Iris setosa, and Iris ensata in the wetland (Nash and Stroupe 2003, Engin et al. 1998, Jacobs et al. 2010, Lee and Kim 2014).

The seedlings were transplanted individually into pots ( $\Phi 13.5 \mathrm{~cm}$; height $12 \mathrm{~cm}$ ), and three pots were placed in a container $(44 \mathrm{~cm} \mathrm{~W} \times 27 \mathrm{~cm} \mathrm{~L} \times 30 \mathrm{~cm} \mathrm{H})$ with a hole for water-level treatment. There were 12 replications of each treatment. Because many of the young seedlings died in previous pilot experiments, hydrology treatment was added after 1 week from transplantation. The water level was checked every day and maintained continuously at the same level throughout the investigation. From June to August, the water was replaced once a week because of algal blooms.

\section{Measurements}

The survival and height were measured twice a week until the end of September, and the longest leaf width and total number of leaves on each plant were measured after the experiments. All the measurements were carried out on non-senescent and non-destroyed leaves. The survival was estimated by assuming that an individual plant died from the time of visible degeneration of the leaves. The longest leaf width was measured across the widest part of the leaf. The height data were fitted to sigmoid curves using SigmaPlot 14 software (Systat Software Inc., San Jose, CA, USA).

Plants were harvested at the end of September, after 16 weeks of transplantation. Before harvest, measurements were made of the longest leaf area and tiller numbers. The harvested plants were separated into below- and aboveground and dried for over $48 \mathrm{~h}$ at $70{ }^{\circ} \mathrm{C}$. After drying, the biomass was determined by dry-weight measurements.

Table 1 Nitrate, ammonium, and phosphate contents in soil before and after experiment (average \pm 1 SD; before, $n=2 ;$ after, $n=4$ )

\begin{tabular}{|c|c|c|c|c|c|}
\hline Soil nutrient level & Treatment & & $\mathrm{NO}_{3}-\mathrm{N}(\mathrm{mg} / \mathrm{kg})$ & $\mathrm{NH}_{4}-\mathrm{N}(\mathrm{mg} / \mathrm{kg})$ & $\mathrm{PO}_{4}-\mathrm{P}(\mathrm{mg} / \mathrm{kg})$ \\
\hline \multirow[t]{4}{*}{ Low (L) } & Before & & $1.35 \pm 0.05$ & $0.40 \pm 0.06$ & $4.46 \pm 0.13$ \\
\hline & After & $-10 \mathrm{~cm}$ & $0.15 \pm 0.02$ & $0.54 \pm 0.09$ & $4.22 \pm 0.22$ \\
\hline & & $0 \mathrm{~cm}$ & $0.13 \pm 0.02$ & $0.60 \pm 0.08$ & $3.62 \pm 0.29$ \\
\hline & & $+10 \mathrm{~cm}$ & $0.17 \pm 0.04$ & $0.80 \pm 0.10$ & $3.83 \pm 0.37$ \\
\hline \multirow[t]{4}{*}{ Medium (M) } & Before & & $23.92 \pm 2.25$ & $33.38 \pm 1.64$ & $24.31 \pm 0.89$ \\
\hline & After & $-10 \mathrm{~cm}$ & $0.27 \pm 0.04$ & $1.91 \pm 0.63$ & $19.29 \pm 2.49$ \\
\hline & & $0 \mathrm{~cm}$ & $0.17 \pm 0.01$ & $1.41 \pm 0.26$ & $19.60 \pm 1.48$ \\
\hline & & $+10 \mathrm{~cm}$ & $0.26 \pm 0.05$ & $3.37 \pm 1.75$ & $20.97 \pm 1.54$ \\
\hline \multirow[t]{4}{*}{ High (H) } & Before & & $60.87 \pm 1.98$ & $96.80 \pm 3.70$ & $56.94 \pm 1.00$ \\
\hline & After & $-10 \mathrm{~cm}$ & $0.94 \pm 0.56$ & $20.09 \pm 6.50$ & $39.47 \pm 4.24$ \\
\hline & & $0 \mathrm{~cm}$ & $0.36 \pm 0.23$ & $16.81 \pm 4.69$ & $34.85 \pm 0.99$ \\
\hline & & $+10 \mathrm{~cm}$ & $0.55 \pm 0.35$ & $26.64 \pm 3.40$ & $32.77 \pm 8.59$ \\
\hline
\end{tabular}




\section{Statistical analysis}

Survival data were analyzed by Chi-square tests at $P$ $<0.05$ levels of significance to compare groups that had received experimental treatments. To determine the effect of water level and soil nutrients on the growth of the I. laevigata seedling, the data were analyzed using analysis of variance (ANOVA) and post-hoc Scheffé's tests at $P<0.05$ levels of significance. All analyses were done using SPSS 20.0 software (SPSS Inc., Chicago, IL, USA).

\section{Results}

The comparison of survival curves using a chi-square test showed a significant difference between all the treatments $\left(\chi^{2}=30.66, \mathrm{df}=8, P<0.001\right.$; Fig. 1$)$. All the I. laevigata seedlings survived for 2 weeks after treatments, and the survival curves for group +10 were steeper than that for groups 0 and -10 . The survival rate did not decrease 50 days after transplantation. At that time, the height of the seedlings was two or three times above the +10 -cm water level (Fig. 2). Therefore, death of seedlings did not occur, even at the +10 -cm water level.

The seedling height increased rapidly with time from the beginning of the experiment, but the growth rate gradually decreased toward the end of the experiment (Fig. 2). Groups with longer exponential phase showed slower times to reach $1 / 2 V_{\max }$ based on trend lines for height and growth. Overall, the time to reach $1 / 2 V_{\max }$ was slower in group $H$ than in groups $L$ and $M$, regardless of the water level. The final height elevated with increased soil nutrients irrespective of the water level. The highest final height was $60.54 \mathrm{~cm}$ at group $0 / \mathrm{H}$, and the lowest height was $24.36 \mathrm{~cm}$ at group $0 / \mathrm{L}$. The height difference was related to soil nutrients $\left(F_{2,83}=223.38, P\right.$ $<0.001)$ and interactions between soil nutrients and the water levels $\left(F_{4,83}=2.52, P<0.05\right)$. However, there was no statistically significant effect of water level $\left(F_{2,83}=\right.$ 0.16 , non-significant.) on plant height. The time to reach $V_{\max }$ was fastest in group $+10 / \mathrm{L}$, which reflects the interaction effect of nutrients and water levels.

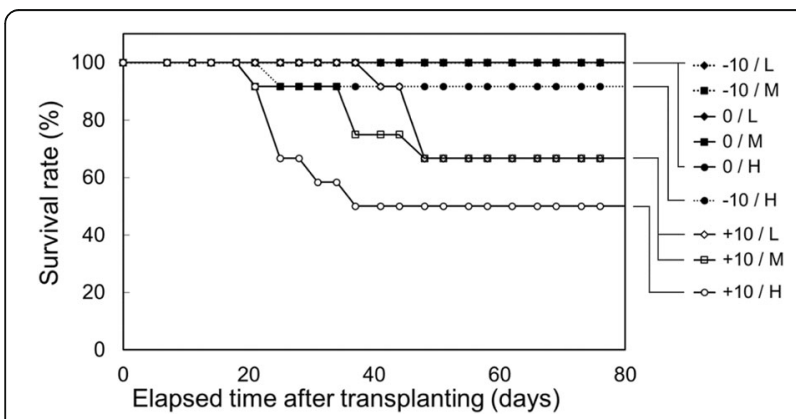

Fig. 1 Changes in seedling survival with time after transplantation of $I$. laevigata under different water level and soil nutrient conditions. There was no change in seedling survival after about 50 days

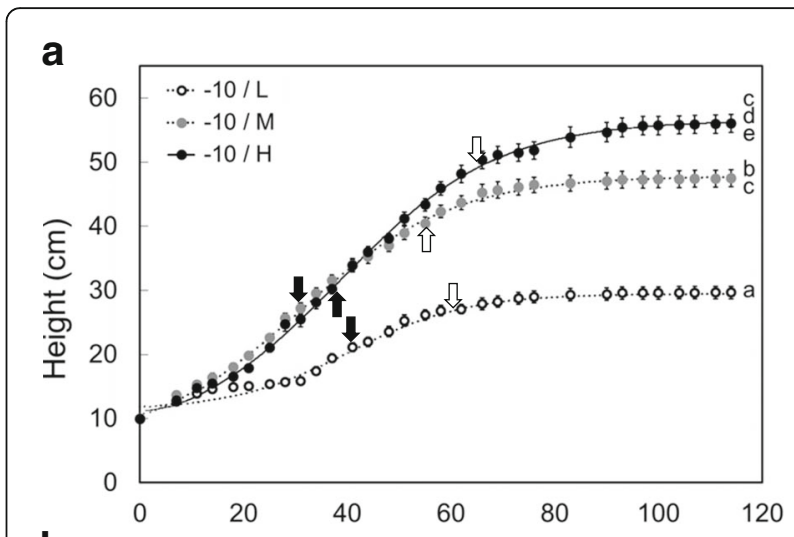

b
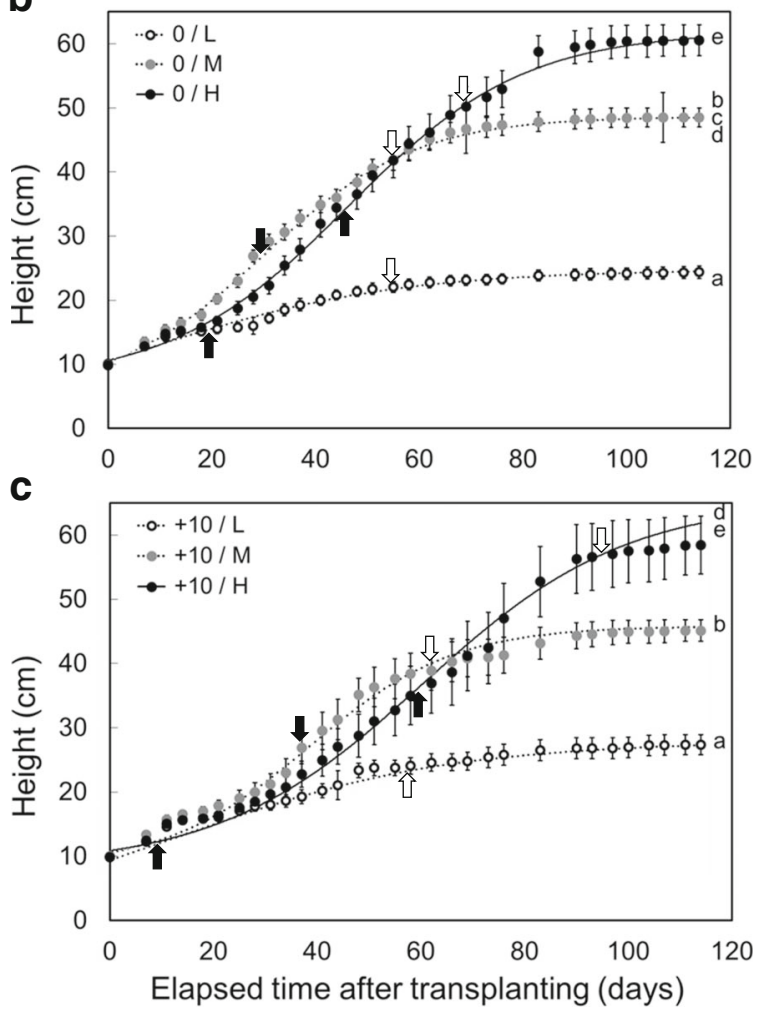

Fig. 2 Changes in height with time after transplanting of I. laevigata under different water level and soil nutrient conditions in alive individuals (mean values $\pm \mathrm{SE}$ ). $\mathbf{a}-10-\mathrm{cm}$ water level, $\mathbf{b} 0-\mathrm{cm}$ water level, and $\mathbf{c}+10-\mathrm{cm}$ water level. Black arrows indicate $V_{\max }$ white arrows indicate $1 / 2 V_{\max }$

The leaf width increased with the increase of soil nutrients at all water levels (Fig. 3a). The largest leaf width was $18.83 \mathrm{~mm}$ for group $+10 / \mathrm{H}$, and the smallest width of a leaf was $3.13 \mathrm{~mm}$ for group $+10 / \mathrm{L}$. The leaf width was related to soil nutrients $\left(F_{2,83}=353.71, P\right.$ $<0.001)$ and interaction between soil nutrients and water level $\left(F_{4,83}=10.31, P<0.001\right)$. However, the effect of the water level was not statistically significant $\left(F_{2,83}=\right.$ 1.14, n.s.). 

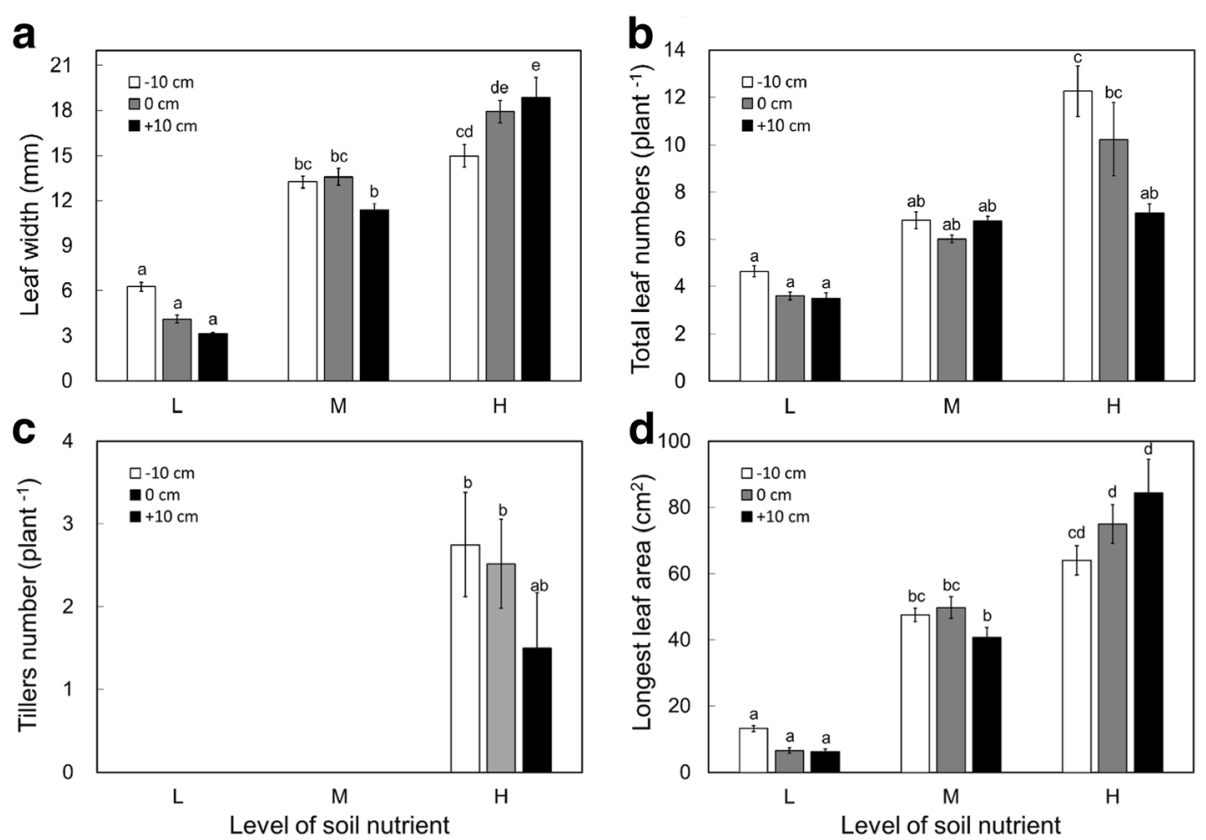

Fig. 3 Leaf width (a), number of total leaves (b), the number of tiller per plant (c) and the area of longest leaf (d) of I. laevigata seedling under different water level and soil nutrient conditions in alive individuals. Vertical bars indicate \pm SE. Alphabetic characters indicate significant differences at the $5 \%$ level based on Sheffé's groups

The number of leaves also increased with the increase of soil nutrients (Fig. 3b). Because tillers occurred in group $\mathrm{H}$ from about 70 days after transplantation, the number of leaves in groups $-10 / \mathrm{H}$ and $0 / \mathrm{H}$ continued to increase until the end of the experiment (Fig. 3c). However, group $+10 / \mathrm{H}$ had a small increase, even under high soil nutrients. The largest total leaf number was 12.26 for group $-10 / \mathrm{H}$. Group $+10 / \mathrm{L}$ had the lowest total leaf number, 3.48, which is thought to be due to a negative interaction between the high water level and the low soil nutrients. The number of leaves was affected by soil nutrients $\left(F_{2,83}=42.94, P<0.001\right)$, water level $\left(F_{2,83}=5.54, P<0.01\right)$, and interaction between soil nutrients and water levels $\left(F_{4,83}=2.66, P<0.05\right)$.

The only group showing increased tiller numbers ( $60 \%$ of vegetative propagation of live plants) was group $\mathrm{H}$ (Fig. 3c). The tiller numbers were significantly affected by soil nutrients $\left(F_{2,83}=42.66, \quad P\right.$ $<0.001)$. Fewer tillers emerged with rising water levels, but there was no significant difference among water levels $\left(F_{2,83}=1.24\right.$, n.s. $)$ and no significant interactions between soil nutrients and water levels $\left(F_{4,83}\right.$ $=1.17$, n.s.).

Similarly to its width, the length of each examined leaf area increased with an increase in soil nutrients (Fig. $3 a-d)$. Areas tended to be lower for group +10 than for group -10 and 0 in the case of both groups $\mathrm{L}$ and $\mathrm{M}$. However, leaf area increased in group $\mathrm{H}$. The largest leaf area was $84.42 \mathrm{~cm}^{2}$ for group $+10 / \mathrm{H}$, and the smallest leaf area was $6.26 \mathrm{~cm}^{2}$ for group $+10 / \mathrm{L}$. The leaf area was significantly affected by soil nutrients $\left(F_{2,83}=206.53\right.$, $P<0.001)$ and interaction between soil nutrients and water level $\left(F_{4,83}=3.97, P<0.001\right)$. However, the effect of the water level was not statically significant $\left(F_{2,83}=\right.$ 0.35 , n.s.).

Plant biomass, both below and above ground, showed a tendency to increase with an increase of soil nutrients at all water levels (Fig. 4a-b). In all soil conditions, group +10 showed the lowest biomass. The below ground biomass was significant affected by soil nutrients $\left(F_{2,83}=85.32, P<0.001\right)$, water level $\left(F_{2,83}=16.03, P\right.$ $<0.001$ ), and interaction between soil nutrient and water level $\left(F_{4,83}=4.63, P<0.01\right)$. The above-ground biomass was significantly affected by soil nutrients $\left(F_{2,83}=127.05\right.$, $P<0.001)$, water level $\left(F_{2,83}=17.25, P<0.001\right)$, and interactions between soil nutrients and water levels $\left(F_{4,83}=4.61, P<0.01\right)$.

The below:above-ground biomass ratio was lower in group $\mathrm{L}$ than groups $\mathrm{M}$ and $\mathrm{H}$. Moreover, the same ratio was lower in group +10 for all the tested soil conditions and under all soil conditions (Fig. 4c). A lower below:above-ground biomass ratio meant that the development of the below-ground part was inhibited, or development of the above-ground portion of the plant was promoted under out conditions. In this experiment, the above-ground part was not promoted for both the group $L$ and +10 . So, it may be the result of a decrease in the below-ground part, especially inhibition of root 


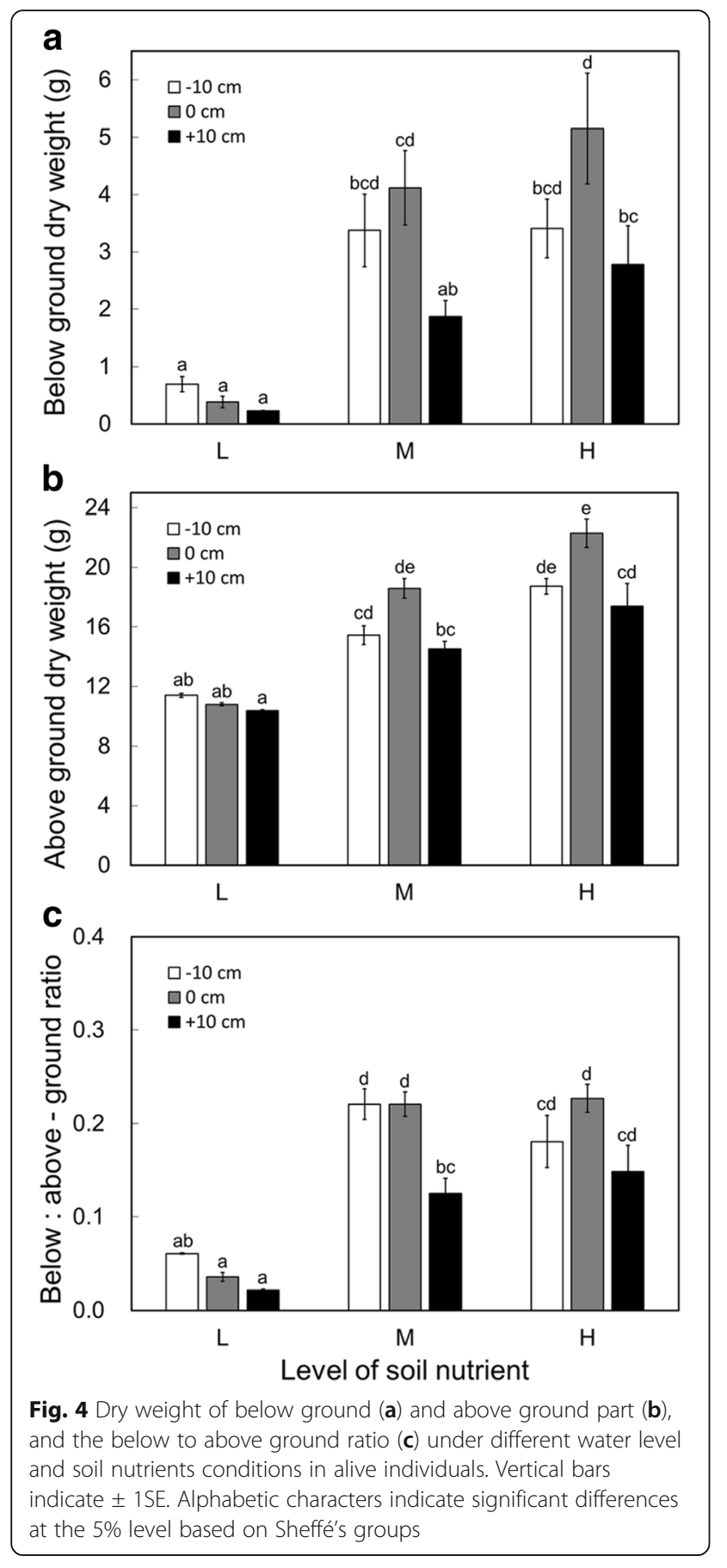

development. The below:above-ground plant biomass ratio was related to soil nutrient $\left(F_{2,83}=104.91, P<0.001\right)$, water level $\left(F_{2,83}=14.20, P<0.001\right)$, and interactions between soil nutrients and water levels $\left(F_{4,83}=3.54, P\right.$ $<0.01$ ).

Seedling growth measurements were significantly impacted by interactions between soil nutrients and water levels. Group $+10 / \mathrm{L}$, which was the most stressful condition, had the lowest value associated with growth
(Figs. 3 and 4). It was the result of the interaction of nutrients and water levels.

\section{Discussion}

The water level is the most important factor affecting seedling establishment and growth of submerged plants (Seabloom et al. 1998). Complete submergence is more stressful than partial submergence. Once plants are completely submerged under high levels of water, the chances to capture atmospheric oxygen and to continue with carbon fixation are restricted, which makes it difficult or impossible to grow and ultimately leads to plant death (Colmer and Pedersen 2008, Sauter 2013). Also, I. laevigata seedling survival is restricted when most of the plant parts are submerged under high levels of water. In fact, the seedlings are more vulnerable than mature plants at the same water level (Pratt et al. 2008, Kim et al. 2013). Rapid seedling growth is required to quickly escape the stressful environment of submergence and low nutrient seedlings (Lacoul and Freedman 2006).

The effects of water level on the total number of leaves, biomass, and below:above-ground biomass ratio showed that the response of each leaf to water level might be different, depending on whether they were completely submerged or partially submerged within the same individual (Figs. 3b and 4). Even at the same water level, the new and smaller leaf is likely to submerge completely and this can cause fatal damage to leaf growth (Striker 2012). Thus, even if the water level is not fatal to survival, it is possible to inhibit the $I$. laevigata seedling growth by damage to new leaf.

Higher soil nutrient level increased plant productivity and above-ground biomass (Figs. 2, 3, and 4). These results suggest high growth and reproduction potential of I. laevigata seedlings in a nutrient-rich environment. Nonetheless, I. laevigata appears as a floating mat in nutrient-depleted environments when the plants are found in their natural habitats in Korea. Under higher nutrient conditions, common species are better able to take advantage of increased nutrient availability compared to rare species, and they have higher relative growth rates and greater biomass than rare species (Clarkson 1967, Chapin et al. 1986). Also, species with higher relative growth rates have difficulties adapting to infertile habitats, and their comparable growth rates decrease more rapidly as fertility decrease (Grime and Hunt 1975, Grime 1979).

The maximum heights of Phragmites australis and Zizania latifolia are 181 and $137 \mathrm{~cm}$, when found in similar environments as I. laevigata floating mats in Korea, even though they are over 350 and $300 \mathrm{~cm}$ in other "fertile" habitats, respectively (Hong et al. 2014, Lee and Kim 2014). Also, I. laevigata showed an early growth of shoot, and shoot height (about $75 \mathrm{~cm}$ ) was 
higher than other accompanying species at flowering season (Lee and Kim 2014). Thus, I. laevigata has advantage to obtain light resources. This explains that some species such as I. laevigata tend to select poor-nutrient habitats rather than compete with other common species in nutrient-rich habitats (Drury 1974).

Living on a floating mat is advantageous to the establishment of seedlings and to the population subsistence of vulnerable hydrophytes. Lee (2012) reported Menyanthes trifoliata living on a floating mat grew and expanded well in non-competitive and nutrient-rich condition, but intercompetition in nutrient-rich environment decreases the growth and propagation remarkably. Shin et al. (2015) also reported that Cicuta virosa lives on a floating mat because a floating mat provides the decreased level of competition due to nutrient limitation under continuous disturbance by water level fluctuation and wind wave action. Both studies suggest that vulnerable hydrophytes may have a strategy to avoid competition in nutrient-rich environment and choose oligotrophic environment even though the growth rate is low.

Water level determines wetland plant community composition and zonation because of different response and adaptation of species (Casanova and Brock 2000). The water level range of floating mat, which is natural habitats of I. laevigata in Korea, on March is 4 to $13 \mathrm{~cm}$ (Lee and Kim 2014). However, the survival data showed that average water level of floating mat in March could almost submerge newly germinated seedlings and interfere the survival and establishment of seedlings. It might be explained that the propagation of I. laevigata by the seeds may be possible only on micro-topography to create a low water level such as tussock grasses in floating mat. After the seedlings have established in sediment with low water levels, they will expand through asexual reproduction such as a tiller.

I. laevigata may use similar survival strategy to Menyanthes trifoliate and Cicuta virosa, which live on floating mat with low nutrient and low competition level (Lee 2012, Shin et al. 2015, Kim et al. 2017). However, since the seedling growth characteristics associated with soil nutrients can vary depending on the competition, further studies focusing on competition is needed. In this study, we could identify the cultivating condition for I. laevigata restoration. This study contributes practical information for the early life cycle of I. laevigata in a wetland that could enhance population sustenance and help to conserve I. laevigata.

\section{Conclusions}

Soil nutrients and water level are critical environmental factors in the establishment and growth of $I$. laevigata seedlings. I. laevigata lives in shallow water level, but seedling does not survive well under submergence. I. laevigata shows better growth and asexual reproduction in higher soil nutrients. This study suggests that I. laevigata does not prefer low nutrient condition but choose another benefit such as low competition. In addition, for effective management, it is important to maintain adequate water level so that I. laevigata seedling are not submerged until sufficient growth occurs.

\section{Abbreviation \\ n.s: Non-significant}

\section{Acknowledgements}

Not applicable.

\section{Funding}

This study was funded by the Korea Ministry of Environment (MOE) as "public technology program based on Environmental Policy" (2016000210003).

\section{Availability of data and materials}

The datasets during and/or analyzed during the current study are available from the corresponding author on reasonable request.

\section{Authors' contributions}

LEH participated in the design of the study, mesocosm experiments, and data analyses and wrote the manuscript draft. LBE obtained the seeds, participated in the design of the study and data analyses, and edited the manuscript draft. KJG conceived the study, participated in the design of the study, edited the manuscript draft, and secured the funding. All authors read and approved the final manuscript.

Ethics approval and consent to participate

Not applicable.

Consent for publication

Not applicable.

Competing interests

The authors declare that they have no competing interests.

\section{Publisher's Note}

Springer Nature remains neutral with regard to jurisdictional claims in published maps and institutional affiliations.

Received: 16 January 2018 Accepted: 30 January 2018

Published online: 07 February 2018

\section{References}

Casanova, M. T., \& Brock, M. A. (2000). How do depth, duration, and frequency of flooding influence the establishment of wetland plant communities? Plant Ecology, 147(2), 237-250.

Chapin, F. S., Vitousek, P. M., \& Van Cleve, K. (1986). The nature of nutrient limitation in plant communities. The American Naturalist, 127(1), 48-58.

Clarkson, D. T. (1967). Phosphorus supply and growth rate in species of Agrostis L. Journal of Ecology, 55, 111-118.

Colmer, T. D., \& Pedersen, O. (2008). Underwater photosynthesis and respiration in leaves of submerged wetland plants: gas films improve $\mathrm{CO}_{2}$ and $\mathrm{O}_{2}$ exchange. New Phytologist, 177(4), 918-926.

Drury, W. H. (1974). Rare species. Biological Conservation, 6(3), 162-169.

Engin, A., Kandemir, N., Şenel, G., \& Özkan, M. (1998). An autecological study on Iris pseudacorus L. (Iridaceae). Turkish Journal of Botany, 22(5), 335-340.

Fraser, L. H., \& Karnezis, J. P. (2005). A comparative assessment of seedling survival and biomass accumulation for fourteen wetland plant species grown under minor water-depth differences. Wetlands, 25(3), 520-530. 
Gaston, K. J., \& Kunin, W. E. (1997). Rare-common differences: an overview. In W. E. Kunin \& K. Gaston (Eds.), The biology of rarity (pp. 12-29). Dordrecht: Springer.

Grime, J. P. (1979). Plant strategies and vegetation processes. Chichester: Wiley.

Grime, J. P., \& Hunt, R. (1975). Relative growth-rate: its range and adaptive significance in a local flora. Journal of Ecology, 63, 393-422.

Hong, M. G., Son, C. Y., \& Kim, J. G. (2014). Effects of interspecific competition on the growth and competitiveness of five emergent macrophytes in a constructed lentic wetland. Paddy Water Environment, 12(1), S193-S202.

Jacobs, J., Graves, M., \& Mangold, J. (2010). Biology, ecology and management of yellowflag iris (Iris pseudacorus L.). Montana: United States Department of Agriculture, Natural Resources Conservation Service.

Kim, D. H., Kim, H. T., \& Kim, J. G. (2013). Effects of water level and soil type on the survival and growth of Persicaria thunbergii during early growth stages. Ecological Engineering, 61, 90-93.

Kim, H. T., Lee, G. M., \& Kim, J. G. (2013). The ecological characteristics and conservation counterplan of Menyanthes trifoliata habitat in floating mat in Korean east coastal lagoon, Sunyoodam. Journal of Wetlands Research, 15(1), 25-34 (in Korean).

Kim, S. H., Nam, J. M., \& Kim, J. G. (2017). Establishment strategy of a rare wetland species Sparganium erectum in Korea. Journal of Ecology and Environment, $41(1), 27$.

Korea Forest Service and Korea National Arboretum. (2008). Rare plants data book in Korea. Pocheon: Geobook.

Kwon, G. J., Lee, B. A., Nam, J. M., \& Kim, J. G. (2007). The relationship of vegetation to environmental factors in Wangsuk stream and Gwarim reservoir in Korea: II. Soil environments. Ecological Research, 22(1), 75-86.

Lacoul, P., \& Freedman, B. (2006). Environmental influences on aquatic plants in freshwater ecosystems. Environmental Reviews, 14(2), 89-136.

Lee, B. E., \& Kim, J. G. (2014). Habitat environmental characteristics of vulnerable plant species Iris laevigata and I. setosa in Korean east coastal lagoons. Incheon: The 4th International Conference of Urban Biodiversity and Design.

Lee, G. M. (2012). Effects of habitat substrates and companion plants on the growth of Menyanthes trifoliate L. in Korean: Seoul National University, Master's Thesis.

Mahoney, J. M., \& Rood, S. B. (1998). Streamflow requirements for cottonwood seedling recruitment-an integrative model. Wetlands, 18(4), 634-645.

Ministry of Environment. (2012). Law of wild animal and plants protection. Seoul: Ministry of Environment.

Nash, H., \& Stroupe, S. (2003). Complete guide to water garden plants. New York: Sterling Publishing Company.

National Institute of Biological Resources. (2012). Flora of hot-spot areas in Korea (I). Incheon: National Institute of Biological Resources.

Nicol, J. M., \& Ganf, G. G. (2000). Water regimes, seedling recruitment and establishment in three wetland plant species. Marine and Freshwater Research, 51(4), 305-309.

Orians, G. H., \& Soulé, M. E. (2001). Whither conservation biology research? Conservation Biology, 15(4), 1187-1188.

Pratt, R. B., Jacobsen, A. L., Mohla, R., Ewers, F. W., \& Davis, S. D. (2008). Linkage between water stress tolerance and life history type in seedlings of nine chaparral species (Rhamnaceae). Journal of Ecology, 96(6), 1252-1265.

Rodionenko, G. I. (1987). The genus Iris L.: questions of morphology, biology, evolution and systematics. London: British Iris Society.

Sauter, M. (2013). Root responses to flooding. Current Opinion in Plant Biology, $16(3), 282-286$

Seabloom, E. W., van der Valk, A. G., \& Moloney, K. A. (1998). The role of water depth and soil temperature in determining initial composition of prairie wetland coenoclines. Plant Ecology, 138(2), 203-216.

Shin, C. J., Nam, J. M., \& Kim, J. G. (2015). Floating mat as a habitat of Cicuta virosa, a vulnerable hydrophyte. Landscape and Ecological Engineering, 11(1), $111-117$.

Striker, G. G. (2012). Flooding stress on plants: anatomical, morphological and physiological responses. In J. K. Mworia (Ed.), Botany (pp. 1-28) InTech.

Sun, M. Z., Li, M. R., Shi, F. X., Li, L., Liu, Y., Li, L. F., \& Xiao, H. X. (2012). Genomic and EST-derived microsatellite markers for Iris laevigata (Iridaceae) and other congeneric species. American Journal of Botany, 99(7), e286-e288.

Yabuya, T. (1987). High-performance liquid chromatographic analysis of anthocyanins in induced amphidiploids of Iris laevigata Fisch. $\times$ I. ensata Thunb. Euphytica, 36(2), 381-387.

Yabuya, T. (1991). Chromosome associations and crossability with Iris ensata Thunb. in induced amphidiploids of I. laevigata Fisch.X I. ensata. Euphytica, 55(1), 85-90.

\section{Submit your next manuscript to BioMed Central and we will help you at every step:}

- We accept pre-submission inquiries

- Our selector tool helps you to find the most relevant journal

- We provide round the clock customer support

- Convenient online submission

- Thorough peer review

- Inclusion in PubMed and all major indexing services

- Maximum visibility for your research

Submit your manuscript at www.biomedcentral.com/submit

) Biomed Central 